Alamein's Encore:

\title{
Entertainment, Information, Intimacy and Reflection in the Boy DVD \\ Director's Commentary
}

O. Ripeka Mercier

In what may be a first for any actor-director, Taika Waititi's DVD audio commentary for Boy is a feature-length conversation between Waititi as Taika, the director, and Waititi as Alamein, the film's protagonist. Multiple role-playing is a feature of Waititi's on-screen and off-screen work, but it is a new phenomenon in the DVD commentary, and it somewhat confounds the current literature in the area. In this article I consider the novel work that Waititi's commentary does to inform the audience. Waititi's entertaining realisation of Alamein as a commentator privileges the director's reading of the character, encouraging the listener to empathise with the film's least sympathetic character. The director's use of the commentary in this way extends his signature approach of multiple role-play, but also plays into the hands of critics who see the DVD as beholden to the auteur project. More significantly however, Waititi's commentary enables him to manage and negotiate expectations of Indigenous authenticity that frame the work of many Māori and Indigenous creatives.

\section{THE DVD AUDIO COMMENTARY}

Films on DVD and Blu-ray are ubiquitous features on our current media landscape, and with many consumers watching and re-watching films in home theatres, it is timely to explore what Indigenous filmmakers bring to this scene. So rather than extending my kaupapa Māori analysis of Boy (2010), I raise a candle to other texts available on the DVD release of Boy, and in particular, Waititi's audio commentary track on the film, available on both the standard release and the 2-Disc Collector's Edition of the Boy DVD. The 2-Disc set includes other special features, such as behind the scenes featurettes with commentary, deleted and extended scenes, outtakes, Waititi's short film Two Cars, One Night (2003), and Waititi's mockumentary-style Crazy Horses recruitment videos, with the latter being distributed online prior to the film's release in Aotearoa.

Waititi is one of a handful of New Zealand directors who have recorded commentaries for the DVD release of their film, in spite of the negligible additional cost in 
producing a director's commentary track. ${ }^{1}$ Other commentaries grace DVD releases of The Piano (2000), Once Were Warriors (2002), Whale Rider (2002), Sione's Wedding (2005), Out of the Blue (2006), The World's Fastest Indian (2006), Eagle vs Shark (2008) and My Wedding and Other Secrets (2011). This is an indicative rather than exhaustive list. Aside from the comprehensive arovideo.co.nz database, which is maintained by librarians who are fastidious about cataloguing accurately, DVD special features are listed spasmodically on mainstream Aotearoa websites that market and sell DVDs. ${ }^{2}$ This lack of director commentary calls into question the extent of the assertion that DVD extras are a marketing device for boosting DVD sales (Bertellini and Reich; Brookey and Westerfelhaus; Grant). While Aro Video observes that "sometimes the extras are the major selling point for purchasing a DVD, especially for a high profile feature film", ${ }^{3}$ it appears that the average Aotearoa online buyer is not demanding this information or is finding it elsewhere, if indeed it is relevant to them.

Waititi's Boy commentary is unique in that it enacts a highly entertaining, informative and reflective exchange between Taika Waititi, as Taika, the director, and Taika Waititi as Alamein, the "inept, wannabe-gangster father" (Lealand, 2011, 5) of the film. Significantly, Waititi may be the first director-actor to stage a feature-length conversation between director and on-screen persona. This is difficult to verify without systematically listening to hours of audio commentaries. Rarely if ever transcribed, commentaries exist as marginal texts, and catalogues of their content currently rely upon users and fans uploading their comments to websites such as ratethatcommentary.com and dvdspecialfeatures.net. Indeed, Ginette Vincendeau noted that this marginality poses some difficulty for checking film students' work, who often now cite commentaries in their research (Bennett and Brown). Thus, the lists provided below are biased towards the commentaries to which I have listened and information available in web-based resources.

Entertainers who re-inhabit their screen personae often do so strategically. For instance in This Is Spinal Tap (2000), the entire cast do their commentaries in character, an

\footnotetext{
${ }^{1}$ A recording studio is often used but is not necessary, as Ronald D. Moore demonstrated in recording podcast commentaries for Battlestar Galactica (2004) using software native to his Apple Macintosh computer, which he set up at home.

${ }^{2}$ Such as screenline.co.nz, mightyape.co.nz, fishpond.co.nz and trademe.co.nz

${ }^{3}$ Andrew Armitage, personal communication, 8 March 2012
} 
approach that is consistent with maintaining the illusion of realism in the mockumentary film. Other actors use this device in isolated or sporadic moments during their commentaries, such as Andy Serkis as Smeagol and Gollum on the actor's commentary of Lord of the Rings: Return of the King Extended Edition (2004) to demonstrate the two distinct voices, and Robert de Niro, to jokingly express paternal frustration with co-star Ben Stiller in the Meet the Parents commentary (2001). Viewers apparently gain much pleasure from this strategy in commentaries, with improvised comedy giving an insight into the skill of the performer. This expectation prompted Screen Rant writer Mike Eisenberg to rate the Tropic Thunder commentary (2008), in which "Robert Downey Jr. provides a second act to his performance as Sgt. Lincoln Osiris" top of his list of 10 DVD/Blu-ray Audio Commentaries You Have to Hear (2010). While most scholars consider information a necessary feature of a "good" commentary (Bennett and Brown; Bertellini and Reich; Parker and Parker), film audiences may be more likely to listen to an actor's commentary for laughs (Pratt) and a sense of intimacy and revelation from the cast, which can occur regardless of how "informative" the commentary is. Indeed, it is strange that more actors don't commentate "in-character". Pratt comments that, "in many cases, actors and actresses by their very nature and vocation are entertaining in the commentary format, and, if they have any intelligence at all, the entertainment is blended seamlessly with enlightenment" (20).

User reviews of DVD commentaries appear to bear this out (Gelman): the commentaries that best reward the average listener are both entertaining and informative. But commentaries are not just about information or entertainment as "a speaker's emotional reaction can be just as valuable..." (Pratt 17). The intimacy possible between a viewer reliving a poignant, emotional or pleasurable screen moment concurrent with the reflection and revelations of an insider is for many a key reason that they listen to commentaries. It is a way to be immersed into the film's process, and the filmmaker's mind and memories. As I will suggest later, commentaries work not just for the audience but also for the commentator. Indeed, Waititi becomes quite reflective himself towards the end of the Boy commentary. 
Some actor-directors, such as Woody Allen and Clint Eastwood, conspicuously do not 'do' commentaries. But the actor-directors ${ }^{4}$ who do are more numerous, ${ }^{5}$ and those who have made semi-autobiographical films, and provided commentaries on their work include Spike Lee for Do the Right Thing (2001), Zach Braff for Garden State (2005) and Roseanne Liang for Banana in a Nutshell (2006). However, in none of the films listed above or in the footnote, does the actor-director explore the to and fro possible in reprising their on-screen role. Taika and Alamein both have quite distinct voices, making for a highly effective commentary that goes beyond what others attempt or achieve, and it is a revealing "extra text" (Brookey and Westerfelhaus) from which to re-read the film.

One of the first texts written about the DVD commentary remarks that it has an "unusual immediacy. It becomes another text; intimately related to the film, complicating the experience of the film, but nevertheless not quite the film" (Parker and Parker 13). The authors discuss how the commentary allows the intentions of the director to be revealed in different ways, knit to specific scenes in the film. It is of note that Taika is more concerned with context and conversation than with stating his intentions, and in this perhaps what he says is mediated by the presence of his fellow commentator (Alamein). Catherine Grant, a contributor to the "What is a DVD?" conference (2005) wrote "the act of selecting the director's commentary turns the 'original' (theatrical) experience of watching the film as fiction into one of watching it 're-directed' or literally re-performed, as a documentary, one in which the film's existing visual track is employed as a graphic illustration of a teleological story of its own production" (Grant 111). Waititi's commentary performs this function primarily through Taika, who is made to assume the role of pedagogue giving insights on pre-production, production and post-production. The commentary achieves something more - an intimacy through Alamein, provided as a documentary revelation of his own life.

Waititi's staging of the duo performing the commentary might raise suspicion amongst some scholars. Grant, for instance, argued that DVDs can be engineered into an

\footnotetext{
${ }^{4}$ I exclude from this definition directors who make cameo appearances in their films.

${ }^{5}$ Actor-director commentaries have also been given by Mel Gibson for Braveheart (2000), Ben Stiller for Zoolander (2002) and others, Denzel Washington for Antwone Fisher (2003), David Duchovny for House of D (2005), George Clooney for Good Night, and Good Luck (2006), Gillian Anderson for The $X$-Files Season 7 episode All Things (2003) and Edward James Olmos for Battlestar Galactica: The Plan (2009), amongst other episodes.
} 
"auteur machine" that can serve to authenticate otherwise 'non-auteur' directors. She cites the example of the double-disc release of the King Arthur DVD (2004) as a way to stamp "commercial auteurism" on Antoine Fuqua (Grant, 105). Commentary allows the director to (even subconsciously) re-inscribe meaning in the authoritative voiceover mode. However, the duo is not signalled in Boy's DVD box description - Alamein's encore is thus uncredited, and when I listened to the commentary, I was surprised to hear it open with Alamein's awestruck reactions to the title sequence. Although Waititi's creative labours on and offscreen have crafted what might be understood as "brand auterism", the concept of "commercial auteurism" does not quite ring true here given the small size of the Aotearoa marketplace.

Another criticism asserts that "audio commentaries tend to provide 'suggested readings' that often crystallize established critical interpretations" (Bertellini and Reich, 105). It has also been argued that the DVD is a medium through which the filmmaker can rail against critical reception of their film - such as the denial of homoerotic overtones in the DVD extras and commentary for Fight Club (2000) (Brookey and Westerfelhaus).

On that score Waititi may be culpable. The 2-Disc Collector's Edition DVD has been engineered to give back story to the character of Alamein. The cover image of the standard edition DVD is filled with the smiling face of James Rolleston as Boy. The cover image used for the Collector's Edition is a wide shot of Rolleston holding a sign saying "Welcome Home Dad", foreshadowing the strong presence of Alamein in that DVD edition. This has the effect of shaping or channelling our perception of Alamein towards Waititi's vision of him as stated in the Boy Press Kit:

In the early stages of the script Alamein is someone who seems so manipulative and cruel, a person few would care to relate to. But I believe in him as a person (I am very protective of all my characters). He needs to be charming and funny, someone you have faith in because underneath you can see the potential, yet he is also dangerous and unpredictable. He is, for me, the most interesting character because of what he represents (Whenua Films, 8).

This reveals Waititi's commitment to unravelling who Alamein is; what he means and to seeing his character's potential fulfilled. However, Waititi speaks from a place of frustration with the stereotyping of (especially male) Māori. "We get portrayed in two ways: Once Were 
Warriors or the blue people in Avatar. I wanted to show we are novel, awkward, clumsy, Indigenous geeks" (2010). Perhaps Alamein's geek stands in for the diverse ways that Māori may potentially be portrayed on film. Thus, we must keep in mind that the work that Waititi does to "suggest a reading" comes from an experience in which Māori concerns on film are frequently misrepresented, misunderstood or judged, as discussed in Jo Smith's article, 'Shaking the Frame: Taika Waititi's Anti-Anthropological Edge' in this issue.

\section{A TYPOLOGY OF COMMENTARIES}

In research on novice, amateur and professional creatives' experiences with limitedtime filmmaking in the 48 Hour Film Competition, we asked competitors to record an audio commentary on their film and reflect on the process. A preliminary finding is that in doing a commentary, learning and insight fold back on the commentator. Thus, the commentary performs a pedagogical function (Smith, 2008) not just in the direction of the DVD consumer (indeed there is no market consumer, as such, for 48 Hour films) but in regards to the creative. Voicing their experiences gave the filmmakers space to reflect upon and receive new insights on their film, as did listening back to their own commentary, whether the commentator was on their own, or with and receiving ideas from others. ${ }^{6}$ Later I explore how Waititi's insights fold back on himself.

In a cast or crew commentary, there are several directions in which the chat may go. From the 48 Hour Film Competition research I developed a typology that serves as shorthand in discussing features of commentary, useful in the ensuing discussion of the Boy DVD. Below I give some examples from the Boy commentary, with the timecode where each example can be found, to illustrate each mode. A commentator's remarks could:

1. address events on-screen, such as "oh, there's some homeless kids" (0:01:52). These comments are prompted by the immediate moment onscreen, but may be temporally displaced as a commentator recalls or anticipates screen moments at other points during the film;

2. be about what's happening in the recording booth off-screen such as Alamein remarking "you're going on a bit there Taika" (0:03:57);

\footnotetext{
${ }^{6}$ Indeed, the connection between audio commentary and learning led me to do a pilot study at Tolaga Bay Area School. It explored how school children's learning could be evaluated by the way they give audio commentaries over educational film resources.
} 
3. discuss the film's production and what happened behind the scenes, such as "that's actually my Uncle Tulo, he's not an actor, or a teacher, he's a fisherman" (0:06:54) or "the song that's coming up is Hine e Hine" (0:52:42), thus behind-screen;

4. tackle issues prompted by what's on-screen, but not related to the film's production, thus beyond-screen. An example would be "Māori have a lot of imagination when it comes to naming their kids" (0:05:00);

5. be directed at us, the spectator, through-screen. Many commentators do this at the beginning, greeting the audience and introducing themselves. Another example from Alamein: "you guys are probably gonna rip off this DVD" (1:23:53).

I developed the above based on the types of comments that emerged from the 48 Hour Film commentaries and from other commercial DVDs. When it came to Waititi's commentary, I found the above typology did not extend far enough so I modified it to include two other modes unique to the Alamein device, whose remarks could:

6. talk directly to-screen, for example, "that's slightly too much hugging you're trying to give me there, kid" (1:13:00);

7. project oneself as though talking in-screen, for example voicing over a character on the screen "I did that. Don't get into the Nazi stuff" (0:18:19).

Waititi has produced four films in the 48 Hour Film Competition, winning the 2004 national final with Heinous Crime, in which he featured as several characters as well as writing and directing. His playing of multiple characters was a feature of all of his subsequent 48 Hour shorts, and this became a highlight of the competition and contributed to his building up a cult following in that sphere. But Waititi is also an experienced actor and stand-up comedian and has written, produced, directed and appeared in numerous dramatic and comedic ventures, such as The Humourbeasts, The Strip, Flight of the Conchords and RadiRadiRah. He has resisted the inscription of "Māori filmmaker" because of the potential limits that this label might place on his artistic expressions. Nonetheless, he is an outspoken advocate for Māori and has demonstrated a commitment to Māori youth. His diverse career as actor, writer, artist, comedian and director gives him a range of techniques to draw upon in his work, which he cleverly deploys in the commentary to the effect of: delivering information as entertainment, elucidating elements of his childhood in 
Waihau Bay from two different perspectives, and engendering empathy for Alamein. In what follows I continue the convention I've used in this article so far, to use 'Waititi' to denote the driver of the commentary, 'Taika' to denote Waititi's director persona and 'Alamein' to denote Waititi's embodiment of the character he plays on-screen.

In addition, Alamein (the commentator) at times reinhabits his on-screen persona by re-rehearsing the film's dialogue in-screen. I am calling this commentary 'character' Shōgun, which evokes the fantasy persona Alamein adopts within the film's narrative. Thus the Shōgun commentator is only enlivened by Alamein re-enacting his role as himself in the film. Shōgun is film-bound, whereas Alamein is the spontaneous incarnation of Waititi's character. Later we will see that Alamein (the commentator) also inhabits other on-screen characters, by speaking their lines in-screen.

\section{ABOUT BOY'S COMMENTARY DUET}

Waititi positions Alamein as the main commentator in a number of ways: he opens and finishes the commentary in character as Alamein, Alamein spends more feature time commentating, Taika plays the straight man to Alamein's funny man, Alamein plays the child to Taika's parent and Waititi engineers Alamein to comment at two key emotional turns in the film. Alamein, in turn, positions himself: as a spectator "writing on a black background, faaar this is incredible" (0:00:35), as an agent in the film-making process "Mean book, Shōgun the book. I actually haven't even read it. In the scenes where you see me reading it, I'm not even reading it. I'm just pretending. It's called acting" (0:20:50) and as the subject of the film "it's a documentary about me and my children" (0:00:58). At several points throughout, Alamein commentates on-screen and beyond-screen, as well as to-screen and in-screen, as though he were reliving real experiences, captured through the independent viewpoint of the camera. The camera is wielded by Waititi, so Alamein is confronted with how Waititi (and the audience) see the incidents in question. As a spectator on the documentary of his own life, Alamein reflects and comments in the moment, and as consumers of the commentary track we become privy to Alamein's intimate reflections. Unknowingly thrust into the viewing room with Alamein, we are forced to choose what to do with his character: hear him out or reject him.

Waititi as director Taika gives a commentary more conventional in form. He comments behind-screen, on the story, production and post-production of the film and he 
talks beyond-screen, giving context and history about place and people, such as anecdotes relating to the on-screen house which is the one in which he grew up. But as the conductor of the Alamein-Taika show, Waititi also fashions a commentary that is rich in off-screen informal conversational element. Taika begins with a riposte to Alamein's claim that the film is a "movie-mentury" (0:01:58), and in doing so also dispenses with the oft-asked question (Lealand 2011, Waititi) of whether his film is autobiographical:

This is not really a documentary, it's a fictional film but it's set in the home town of myself and Shōgun, in a place where we grew up and it's based loosely on, I guess, my childhood, but most of the things in the film are fictitious. (0:02:28)

Waititi's sustained performance of multiple personae (as Alamein, he impersonates four other characters in the film - Boy, Rocky, Juju and Chuppa) renders his commentary as a particularly dense and complex text. In what follows I explore in more detail what the commentary reveals about Waititi's aims by examining in turn the three areas of entertainment, information and reflection and intimacy.

\section{Entertainment}

As stated in the introduction, Waititi's delivery of a feature-length conversation between Taika the director and Alamein the star is a rare approach, so it has a novelty value that is inherently entertaining. It appears to be unrehearsed, yet the banter is convincingly performed with the off-screen exchange producing funny moments, quite aside from the entertaining on-screen and behind-screen revelations that Taika and Alamein share. Waititi's reliving of the core Alamein character also allows Shōgun an encore to his comedic antics in the movie. Alamein's accent has a rural Māori intonation and he deliberately mashes his grammar, for example, "Making movies is probably one of the most interestingest things that has ever been invented, even more interestinger than fighter jets or ice cream" (0:06:27), strongly reminiscent of comedian Billy T. James' work. Waititi's spot-on voice work (accent, grammar, pronunciation and idiom) rewards local audiences. Non-Aotearoa viewers may find it difficult to distinguish the commentary voices, but Waititi orients the viewer through frequent use of names, as his commentary characters address each other. Waititi's aim in voicing two characters for the commentary may have been less consciously to entertain, as it is an extension of the laconically humorous way that the director 
communicates in public in interviews. In this section I look at selected commentary moments, and consider the work they do beyond what the film is able to.

During the commentary of two of the film's most poignant moments - involving Shōgun's confrontation with Boy outside the local shop, and Boy's own attack on Shōgun Alamein as commentator breaks into an improvised song that draws upon visual elements on-screen. Other DVD commentaries feature singing, ${ }^{7}$ but I have not heard a song composed in the moment as Alamein does. As a commentator he is able to disengage from the emotional confrontation on-screen in a way his in-screen alias, Shōgun, cannot, because he is trapped in the moment. Alamein's superficial performance reveals a deep sadness and regret, and an evasion of direct confrontation with his actions on-screen. While singing works as an entertaining strategy, it also draws attention to Alamein's regret about the incidents, and his inability to deal with his actions like an adult. Nonetheless, Alamein does not avoid the confrontation altogether, which he could easily have done by commenting off-screen, beyond-screen or temporally displaced on-screen. Indeed, he anticipates the moment, as I discuss later. Alamein singing his voiceover draws attention to the visual but releases us from the sonic shockwaves of Shōguns stripping and debasement of Boy, allowing us to focus instead on the catharsis of Alamein's remorse. He distracts himself and entertains the listeners at the same time. Waititi's signature combination of comedy and pathos is evident here, the extra-textual commentary allowing Waititi to sweep his authorial brand into the text from the sidelines.

Pop culture references are liberally used in Boy as a way to illustrate the contribution that 80 s culture makes to the characters' life worlds, with Boy's fantasies of Alamein as Michael Jackson and a samurai warrior serving as direct visual references. Both Alamein and Taika intertextualise in their commentary, leaping from on-screen to beyond-screen remarks. For instance Taika describes Weirdo as the "Māori Firpo", a character from the

\footnotetext{
7 Title themes seem to get commentators humming or singing along. Jacqueline Pearce, Sally Knyvette and Stephen Greif hum along to the Blake's 7 (2004) orchestral piece, and Craig Charles, Chris Barrie, Danny John-Jules, Robert Llewellyn and Hattie Hayridge sing the Red Dwarf (2004) title theme.
} 
Bruce Mason play End of the Golden Weather (1962), while Alamein likens Weirdo to a "Māori Kojak". ${ }^{8}$

On-screen connects to beyond-screen in other ways too. Alamein speaks through-screen at us to justify the on-screen smoking in Boy and Rocky's bedroom: "now yous all probably think that smoking round kids is a bad thing, well, ah, it is, it is a bad thing, it's irresponsible, but in the 80s that wasn't really frowned upon as much as now, so shut up" (0:17:38). As such, not smoking inside would have been an anachronism.

Many have found the premise of Nan leaving the kids incomprehensible. On this Alamein remarks, "don't judge her because that was normal in those communities in the 80 s because we were all protected as kids, and people around the neighbourhood would always look out for each other" (1:15:30). Waititi's use of Alamein's voice to share this beyond-screen context has an internal logic; first, we hear it from the insider and second; it means that context is served to us in the funny voice. This allows the audience to absorb the information in a personal rather than removed way.

Physical comedy is a feature of Taika's work, and physical comedy off-screen is hinted at when Taika and Alamein high-five each other (!) Alamein shares with us how that appeared: "that's right, yeah high-five Taika, high-five Alamein [clap noise]. Cool that when we high-fived each other it looked like a guy just clapping his hands" (1:08:54). Taika and Alamein speak not only to each other off-screen, but through-screen to us, their audience. ${ }^{9}$ Alamein in particular also speaks in-screen, reinhabiting and directly overlaying the film itself. In one example he synchronises his off-screen commentary with the lines spoken on-screen:

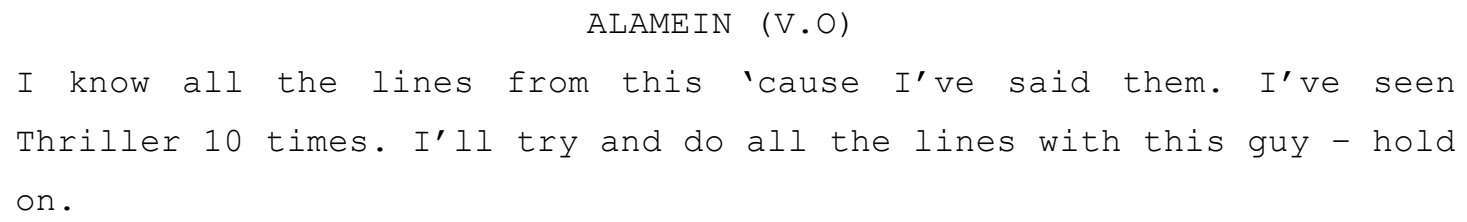

\footnotetext{
${ }^{8}$ Note that Alamein draws on more popular, overseas, references whereas Taika voices the more local one.

${ }^{9}$ In a sense, a commentator's whole performance is through-screen.
} 


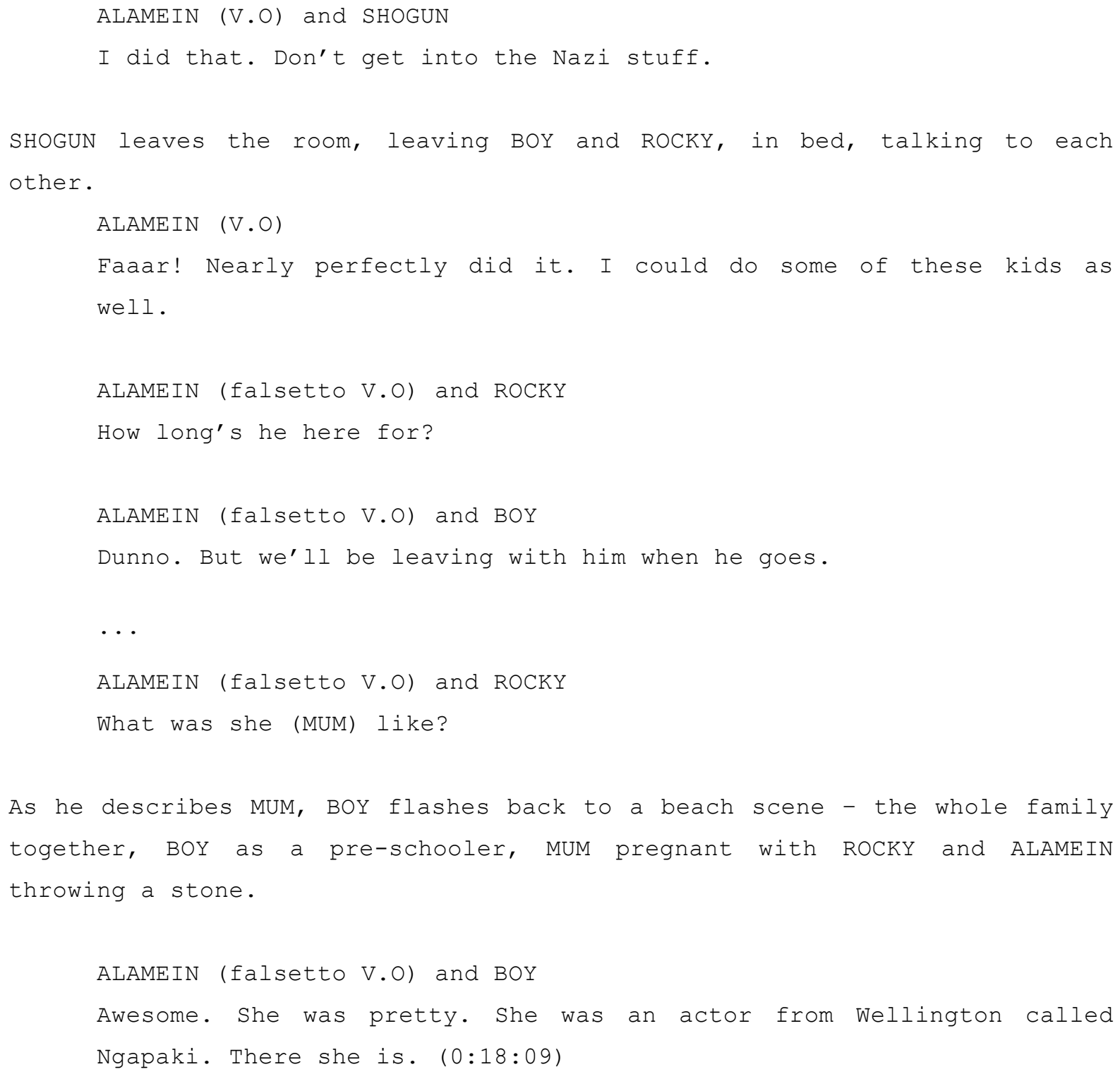

At the end of this sequence we see Alamein slip from re-performing (and re-interpreting) dialogue on-screen, to performing information behind-screen (in this case, a note about Ngāpaki Emery who played Joanie Ranginui, Boy's mother), by co-opting James Rolleston's 'voice' in-screen. While the film text is the canvas from which commentators are prompted to speak, this in-screen dialogue spins in directions that would have been impossible with the standard 'in-person' (rather than in-character) commentary. The comedic elements, while there to provide laughs and arising from the moment, nonetheless reveal information, allowing a more pleasurable unfolding of harsh narratives. 


\section{Information}

The commentary allows Waititi to give context to the images presented on screen, some of which appeared not to translate to some audiences. In a sense, Waititi "talks in" (Barclay, 1990) through Boy the film, with different audiences (for example, Whānau a Apanui, Māori, Aotearoa, Indigenous, the world) able to access the film with different levels of understanding. In the commentary he "talks out", widening the access point for his audience, and using Alamein's light commentary to moderate listener fatigue from information overload.

Taika and Alamein both speak fondly beyond-screen of the artefacts of the 80 s world in which they grew up, but in different ways. When Alamein sees a television set and hears the Goodnight Kiwi theme on-screen he remembers and lists his favourite TV shows of the 80s: "Knight Rider, A-Team, the Incredible Hulk, Blake's 7, Doctor Who, The Triffids, After School..." (0:54:22). Taika talks more abstractly about growing up in a world without cell phones and Facebook, "I liked the times when this guy here, Michael Jackson, was a hero and you had to make your own fun outside, on the beach, playing with sticks and stuff" (0:03:36). The duo device is exploited by Waititi at a couple of junctures to point out the additional work Taika did beyond writer-director-actor of the film. For example, thirteen minutes into the film Taika draws attention to the uncredited coloured pencil animations on-screen:

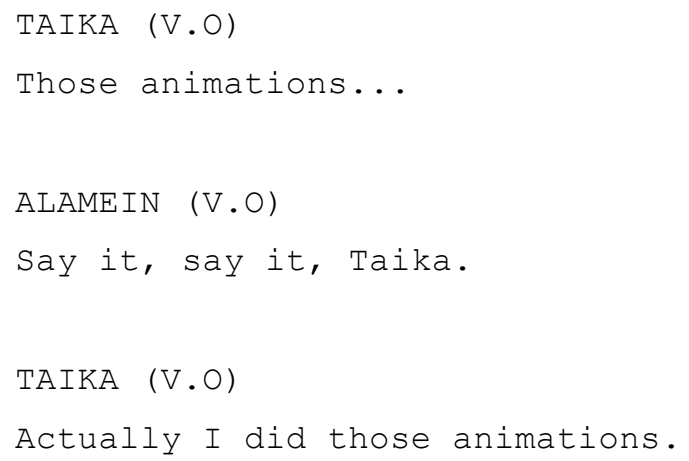

And during the encounter scene over the kitchen table (0:15:41), between Alamein, Juju and Chuppa, and Boy, Rocky and Kelly, Alamein compliments Taika on the shot composition.

Alamein's commentary allows a more contextualised and sympathetic reading of the character of Alamein, demonstrating the paratextual work that commentaries can do. 
Leading up to the on-screen encounter outside the shop, Alamein gives an account of his behaviour:

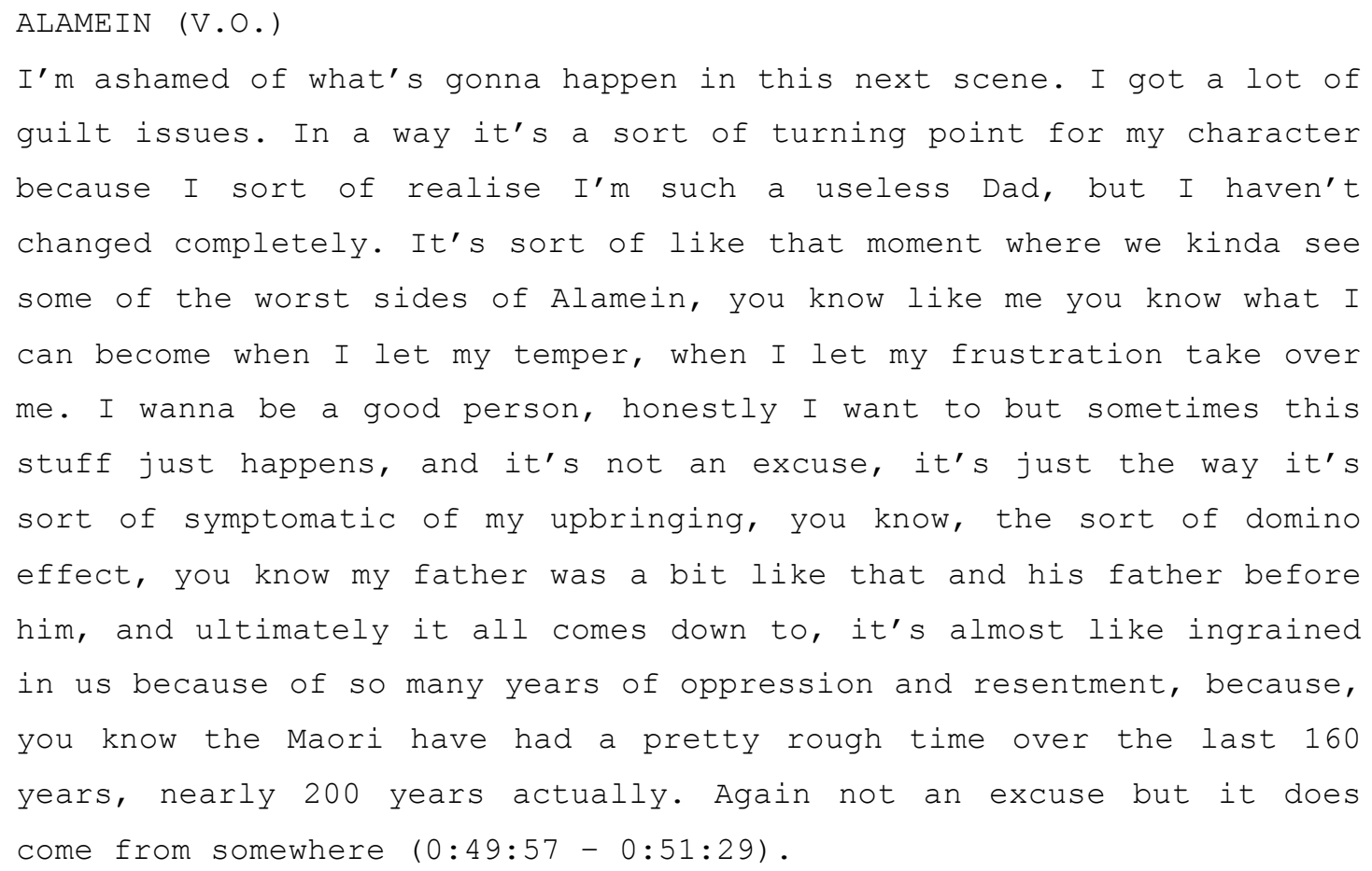

Alamein does not excuse his behaviour as the incident looms on-screen, he even anticipates it. When Waititi as Alamein comments on inherited violence resulting from colonial oppression, he gives a genealogy of substance abuse and violence. Many, such as Leonie Pihama (Dennis and Bieringa), criticised Once Were Warriors for lacking this context, as summed up here:

Criticisms have been levelled at the film for decontextualising the circumstances of the family. There is no reference to colonial depredation, other than the fact that the only Pakeha roles in the film are as agents of the law... with no exploration of these contexts, the family circumstances could be seen to be all of their own making, unconnected to loss of land, culture and sovereignty associated with colonialism. (Treagus in Lealand 2008, 268269)

Boy is not as physically violent as Once Were Warriors, with Shōgun, Juju and Chuppa the only ones to get an on-screen beating through non-explicit violence, Joanie (Boy's mother) dying off-screen and before the film, and Dynasty's black eye implying a beating off-screen. Joyce adds that, "The comedy in [Boy], although frequently dark, strikes an effective middleground position between the horror of [Once Were] Warriors and the escapism of Whale 
Rider" (236). Where Once Were Warriors left many thinking they had seen a documentary depiction of urban Māori life, Alamein's commentary gently lampoons this expectation, but also does serious work to enunciate the impacts of colonisation. Notably, it is the DVD commentary that gives this context, and not the film. Thus, while Boy and Once Were Warriors are equally complicit in not directly addressing colonial depredation, Waititi exploits the DVD format to share this. DVD thus offers perspectives beyond "commercial auterism" and "brand auterism".

\section{Reflection and Intimacy}

Alamein talks through-screen to the audience in a way that acknowledges our presence, assumes that we are listening (as opposed to the rather irritating habit of commentators who question "does anybody actually listen to these things?"), and even in a way that imagines possible future interactions between him and us. For example, of the Crazy Horses' hand sign he threatens:

I don't want to hear any comments that our sign looks like a duck. It's not a duck, it's a horse head. And that's a machete that I will introduce to you if you say it is a duck head. It's a horse head. And that's a book that I will dong on your head too. (0:21:06)

A seldom recognised reason for which people listen to commentaries is to be rewarded by being treated as an insider when commentators talk through-screen, with intimacy. Some commentaries achieve this better than others. The Toronto Sun called Sacha Baron Cohen's commentary for the Bruno DVD (2009) open, thoughtful and candid, an uncommonly intimate approach for the British comedian, who slips into character (as Ali G or Borat) to give public interviews.

As with the amateur filmmakers in our study with 48 Hour Film Competition participants, professional commentaries are rarely rehearsed ${ }^{10}$ - people speak in the moment, perhaps with reference to notes, but generally taking only the film itself as their referent. The preliminary results of our 48 Hour Film research suggest that recording a commentary, and then listening to that recording with the film, can provide impromptu revelations to the commentator. In a survey of competitors who had listened back to their commentary, all agreed or strongly agreed that it was amusing and made them remember

${ }^{10}$ Academic commentaries, on the other hand, are almost invariably pre-written, sometimes rehearsed and frequently edited to fit the film track (Bennett and Brown). 
events. Half of those surveyed strongly agreed that it gave them new insights on the film, or the film-making process, with the other half neither agreeing nor disagreeing. This seems to imply a connection between the recorded commentary and memory, and bears further study.

In a reflective moment towards the end of Boy, Alamein remarks to Taika off-screen that the commentary had become more like people talking while watching the film. He asks Taika whether he was able to keep his directing and acting roles separate:

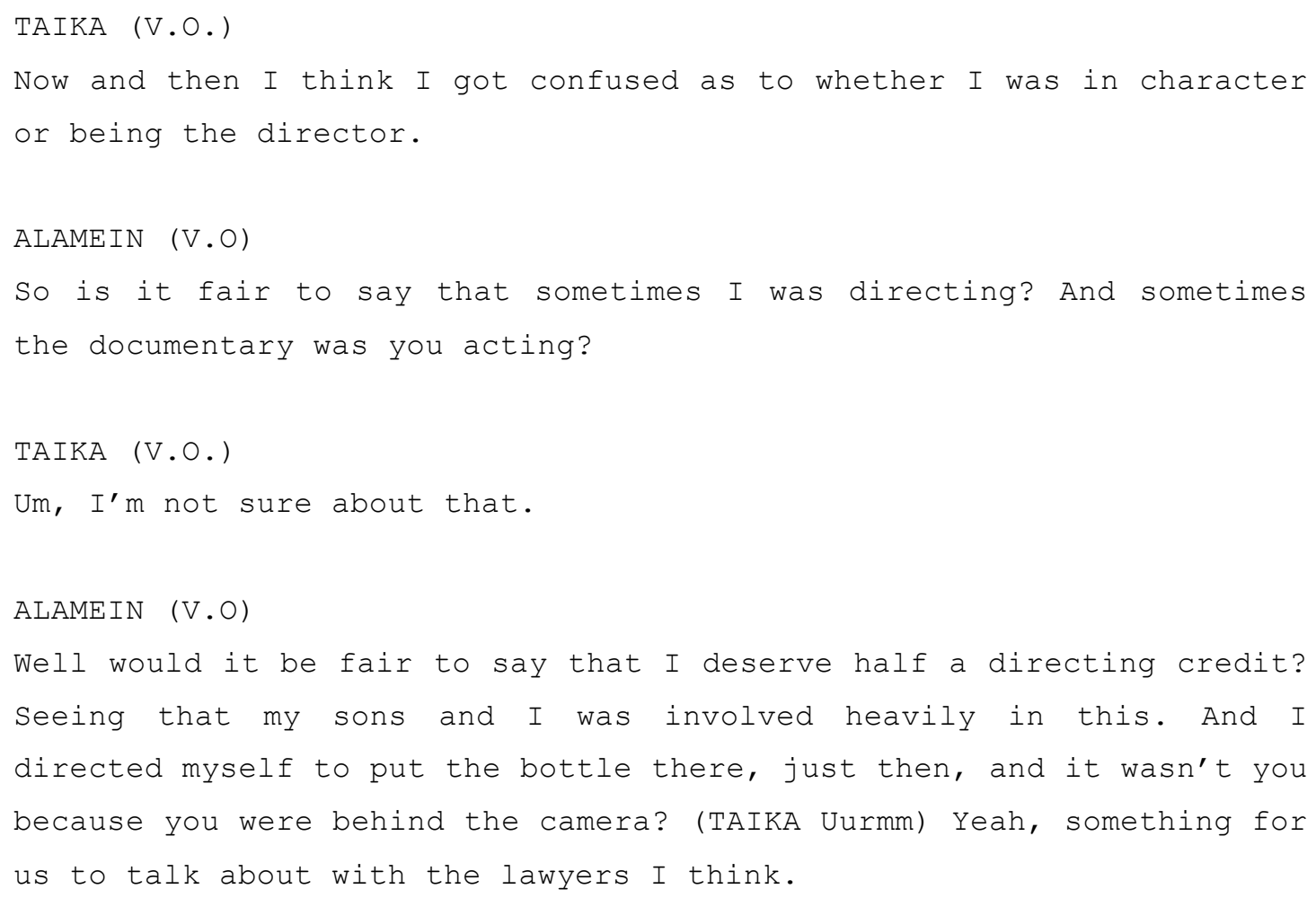

In Waititi's rendering of Alamein and Taika's conversation, he informs us off-screen and beyond-screen with a masterful exploration of commentary techniques that surprises and entertains, while fostering reflection and intimacy.

\section{CONCLUSION}

The character of Alamein is a comedic figure, but in playing himself straight he gives us intimate access to the world inhabited by Shōgun. Waititi's magnificent achievement Boy the film - is rendered even more remarkable by his unheralded rendering of Alamein's commentary on his own life. 
The commentary demonstrates Waititi's empathy with Alamein, and he could be accused of engineering the DVD to channel our perception of the character by exploiting his ability to inhabit multiple personae. Indeed, some may have preferred to hear a commentary from the film's true central characters, Boy and Rocky. However, in speaking through Alamein, Waititi can directly address difficult issues that underlay the film, using his signature approach of comedy mediating tragedy. By analysing aspects of Waititi's commentary with a new typology, I have revealed the entertaining, intimate and reflective ways Waititi commandeers the commentary to inform the audience about the very issues that are not overtly stated in the film.

Boy is a rich text but Waititi's commentary, seen as paratextual to the film, renders Boy even richer. As its own self-reflexive text, the commentaries provide much food for thought for current DVD scholarship. The commercial auterism concept does not fit the rendering and marketing of Waititi's commentary, so I have suggested 'brand auterism' as an alternative. However, neither term captures the work that the DVD commentary can do in negotiating the expectations placed on Māori to be and do certain things in their creative work. In addition, this commentary cannot be fully understood as a pedagogical 'making-of' directed out to the audience. Commentary also causes creatives to reflect upon and learn from the process for themselves. Finally, Alamein's to-screen and in-screen moments required that I extend my typology of commentary comments. Thus Waititi's approach confirms, confounds and stretches current understandings of DVD commentary.

\section{ACKNOWLEDGMENTS}

This article was written while on a research sabbatical, and I am grateful for financial support from the Faculty of Humanities and Social Sciences, Victoria University of Wellington, and institutional support and academic feedback from members of the Royal Holloway University of London's Indigeneity in the Contemporary World: Performance, Politics and Belonging research group. I acknowledge research assistant for the 48 Hour Film work, Challen Wilson, who developed the idea of using the script format to present commentaries in her Honours research essay. I also acknowledge feedback on the original paper that I gave at the Boy symposium, particularly from Robin Cohen.

Ocean Ripeka Mercier is a lecturer in Te Kawa a Māui (the School of Māori Studies) at Victoria University of Wellington. She started her research career in physics and with a passion for teaching, and her current teaching and research extends that focus into Māori 
studies through work at the interface between mātauranga Māori and science, particularly in educational contexts such as the Te Kawa a Mãui Atlas project (http://www.victoria.ac.nz/maori/atlas) and she is the presenter of Māori Television's Project Mātauranga. Ocean's research also explores kaupapa Māori analyses of Taika Waititi's films. She also leads a nationwide enquiry on the V48 Hours Furious Filmmaking competition.

\section{WORKS CITED}

Barclay, Barry. Our Own Image. Auckland: Longman Paul, 1990. Print.

Bennett, James and Tom Brown. 'The Place, Purpose and Practice of GBI's DVD Collection and the Academic Film Commentary: An Interview with Caroline Millar and Ginette Vincendeau'. Film and Television After DVD. Eds. James Bennett and Tom Brown. New York: Routledge, 2008. 129-148. Print.

Bertellini, Giorgio and Jacqueline Reich. 'DVD Supplements: A Commentary on Commentaries'. Cinema Journal 49.3 (2010): 103-105. Web.

Brookey, Robert Alan and Robert Westerfelhaus. 'Hiding Homoeroticism in Plain View: The Fight Club DVD as Digital Closet'. Critical Studies in Media Communication, 19.1 (2002): 2143. Web.

Dennis, Jonathan and Jan Bieringa. Eds. Film in Aotearoa New Zealand. (Second edition). Wellington: Victoria University Press, 1996. Print.

Dunleavey, Trisha and Hester Joyce. New Zealand Film and Television Institution, Industry and Cultural Change. Bristol: Intellect Books, 2011. Print.

Eisenberg, Mike. '10 DVD/Blu-ray Audio Commentaries You Have To Hear'. 2010. Web. 15 February 2012. <http://screenrant.com/10-dvd-commentaries-you-must-hear-mikee$50351 />$.

Gelman, Herschel. 'RateThatCommentary.com'. 2006. Web. 20 February 2012. <http://ratethatcommentary.com/>.

Grant, Catherine. 'Auteur Machines? Auterism and the DVD'. Film and Television After DVD. Eds. James Bennett and Tom Brown. New York: Routledge, 2008. 101-115. Print. 
Lealand, Geoff. 'The Cinema of Australia and New Zealand'. European Journal of Communication 23.2 (2008): 246-249. Web.

---.'Boy, Oh Boy! An Interview with Taika Waititi'. Script 76 (2011): 5-7. Web.

Mercier, Ocean Ripeka. 'Welcome to My Interesting World: Pōwhiri Styled Encounter in Boy'. Illusions 42 (Winter) (2010): 3-7. Web.

Parker, Deborah and Mark Parker. 'Directors and DVD Commentary: The Specifics of Intention'. The Journal of Aesthetics and Art Criticism 62.1 (2004): 13-22. Web.

Pratt, Douglas. 'The Best DVD Audio Commentaries'. Cineaste (Summer 2010): 17-21. Web.

Smith, Jo. 'DVD Technologies and the Art of Control'. Film and Television After DVD. Eds. James Bennett and Tom Brown. New York: Routledge, 2008. 129-148. Print.

Waititi, Taika. 'Boy Q and A'. Sundance Film Festival. 2010. Web. 26 February 2012. $<$ http://www.youtube.com/watch?v=I_OkifYQbVI\&feature=related>.

Whenua Films. Boy Press Book. Wellington: Whenua Films, 2010. 8. Print. 